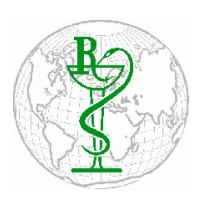

INDO GLOBAL JOURNAL OF

PHARMACEUTICAL SCIENCES

ISSN 2249- 1023

\title{
Pathogenic Effects of Three Species of Fungi (Aphanomyces laevis, Aspergillus niger and Saprolegnia parasitica) on Gold Fish (Carrasius auratus L.)
}

\author{
Rekha Chauhan ${ }^{*}$, Majid Hassan Bhatt, Showkat Aziz Lone \\ Department of Zoology and Applied Aquaculture, Barkatullah University, Bhopal, India
}

Address for Correspondance: Rekha Chauhan, rekhatarun98@gmail.com

\begin{abstract}
Present study was conducted to find out the pathogenicity of three species of fungi,viz. Aspergillus niger, Aphanomyces laevis and Saprolegnia parasitica isolated from Gold fish (Carrasius auratus) collected from pet shops. Experiment

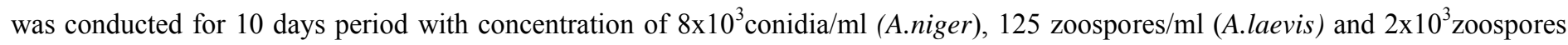
$/ \mathrm{ml}$ (S.parasitica). All the tested fungi were found pathogenic to fish. Among the three species of fungi tested, A.laevis and S.parasitica showed $100 \%$ mortality in fish while A.niger showed $75 \%$ mortality. S.parasitica was found most virulent causing mortality within six days of experiment. Histopathological examination of fishes showed inflammation of epidermis, loss of epidermis and necrotized hypodermis. Degenerative changes were observed in musculature. Ulcerated skin showed mycotic granulommas. (C) 2014 iGlobal Research and Publishing Foundation. All rights reserved.
\end{abstract}

KEYWORDS: Gold Fish; Pathogenicity; Histopathology; Fungi.

\section{INTRODUCTION}

In India variety of fresh water and marine ornamental fishes are available. According to the reports of Central Marine Fisheries Research Institute about 600 species have been identified as potential fishes with ornamental value. The trade in India fetches about 50 crores/year. Fungal infection is very common in ornamental fishes including gold fish (Carrassius auratus) which is most domesticated fish. Mostly fungal infection in fish is called Saprolegniasis caused by members of family Saprolegniaceae ( Saprolegnia and Achlya). In aquariums gold fish is mostly attacked by fungus due to change in temperature and filthy conditions of water which allow excessive zoospores to grow and the ammonia which is formed by rottening of fish waste wears away the mucus that protects the skin. Isolation of Saprolegnia, Aphanomyces and Aspergillus have been reported from ornamental fish by numbers of workers like ( Khulbe,1983: Salem et al.,1989; Hatai and Hoshiai,1992b; Hatai et al.,1994; Shrivastava,1996; Qureshi et al.,2002; Sosa et al.,2007; Siddiqi et al., and Shabzan et al.,2009; Refai et al.,2010;Das et al., and Chauhan et al.,2012.)
(Chauhan,2012) also reported Saprolegnia, Aphanomyces and Aspergillus from ornamental fishes. Three species of Aspergillus have been reported from ornamental fishes by Chauhan,2013; Iqbal and Mumtaz,2013) reported Aspergillus from gold fish. Studies on pathogenicity of fungi on gold fish and histological alterations in the infected tissue have been very rare and not been well documented. Present investigation have been designed to find out the fungi involved in mycotic infection in gold fish. The study also describes the experimental exposure of gold fish to isolated species of fungi and histopathological changes in tissue of infected area.

\section{MATERIALS\& METHODS}

A total number of 37 gold fishes (Carrasius auratus) were collected from different pet shops of Bhopal in the period of four months, September,2013 to December 2013. Infected fish were brought to the laboratory in sterilized polythene bags for isolation of fungi. Temperature, $\mathrm{pH}$ and $\mathrm{D} . \mathrm{O}$ of aquarium 
Indo Global Journal of Pharmaceutical Sciences, 2014; 4(2): 41-46

water was observed at the same time with digital meters (Hach,India).

The fishes were kept in aquaria with continuous aeration. The fishes were observed to note external symptoms. To avoid bacterial contamination all the glass wares, instruments and media were sterilized, along with all aseptic conditions, Streptomycine sulphate $100 \mathrm{mg} / \mathrm{ml}$ were used in media. Innoculation was done in Laminar flow in sterilized conditions. The agar plates were incubated at $18 \pm 2^{\circ} \mathrm{C}$ for the growth of cultures of zoosporic fungi and for conidial fungi cultures were kept at $28+2^{\circ} \mathrm{C}$. Full growth of colony was observed in 6-8 days. Media used in the study were Sabourauds Dextrose Agar and Corn Meal Agar. Pure cultures were prepared by single hypha method. Identification of fungi was carried out on the basis of keys of ( Raper, 1965; Refai et al.,1987; Willoughby, 1994; Khulbe, 2001 and Shrivastava,2009).

\section{Experimental infection trials}

To determine the pathogenicity of isolated species of fungi pure cultures were prepared on CMA and SDA and maintained at required temperature. Zoospores concentration was prepared as wet cultures by using baits, Glycine seeds (Soyabean) for Saprolegnia and Sorghumseeds (Jowar) for Aphanomyces. Conidial suspensions was prepared on media. Concentrations were prepared by using haemocytometer.

Healthy fishes with average length of $10.5 \pm 2 \mathrm{~cm}$ and average weight of $18 \pm 4$ gmwere collected and kept in aquaria of $10 \mathrm{~L}$ capacity under observation for three days with continuous aeration and fed with artificially. For experimental purpose fishes were injected intramuscularly with $0.1 \mathrm{ml}$ of concentration of each species of fungi Aspergillus (8x10 ${ }^{8}$ conidia/ml), Aphanomyces (125zoospores $\left./ \mathrm{ml}\right)$ and Saprolegnia $\left(2 \times 10^{3}\right.$ zoospores $\left./ \mathrm{ml}\right)$.Temperature was maintained as $18 \pm 2^{\circ} \mathrm{C}$ and $28 \pm 2^{\circ} \mathrm{C}$ for zoosporic and conidial fungi respectively. Fishes were observed for 10 days and morbid fish was immediately removed from trough for re isolation and histological examination. For histological studies standard methods given by Roberts, 2001 were followed. Tissue was fixed in aqueous Bouin's fluid for 48-72 hours, processed routinely and slides were prepared by using Haemetoxilyn and Eosin stain.

\section{RESULTS\& DISCUSSON}

A total number of 37 infected fishes were collected for mycotic examination. Among them S.parasitica was isolated from 21 specimens, A.laevis from 9 fishes and A. niger from 7 fishes. The symptoms are white fungoid patches on body, ulcers with hyphal growth and darkening of skin with black patches (Fig-1-6). Average values of water quality parameters were, temperature $\left(18 \pm 3^{\circ} \mathrm{C}\right), \mathrm{pH}$ (7.2-8.0), D.O (6-10.2). S.parasitica have been isolated from gold fish by (Tiffney,1939 b; Sati et al.,1982 and Khulbe,1989).Isolation of A.laevis have been reported from ornamental fish by (Shrivastava and Shrivastava,1977and 1979b).Aspergillus.spp. have been reported from gold fish by (Iqbql et al.,2012 and Iqbal and Mumtaz,2013). (Chauhan, 2013) reported A. niger from ornamental fish. Present findings are supported by reports of given workers.

Results of artificial infection showed that all the three species of isolated fungi were found to be pathogenic to fish.

S.parasitica:-Artificially challenged fish showed external lesions on skin with $25 \%$ mortality on $2^{\text {nd }}$ day, $25 \%$ on $4^{\text {th }}$ day and rest $50 \%$ died on sixth day with ulcers surrounded by mycelium on body surface. It shows $100 \%$ mortality within six days of experiment.

A.laevis:-On the second day only behavioral changes were observed.25\% mortality was recorded on $4^{\text {th }}$ day and $37.5 \%$ mortality was recorded on $6^{\text {th }}$ and $8^{\text {th }}$ days respectively. Ulcers were observed in all the fishes but size of the ulcers were very small with tiny threads of mycelium. Mortality was $100 \%$.

Table-1.Pathogenicity of three species of fungi (Aphanomyces laevis, Aspergillus niger and Saprolegnia parasitica )on gold fish (Carrasius auratus $\boldsymbol{L}$.)

\begin{tabular}{|c|c|c|c|c|c|c|c|c|c|c|}
\hline S. no. & $\begin{array}{c}\text { Fungi } \\
\text { injecte } \\
\text { d }\end{array}$ & $\begin{array}{c}\text { No. of } \\
\text { fish } \\
\text { used }\end{array}$ & $\begin{array}{c}\text { Conc. of } \\
\text { spores/ml }\end{array}$ & \multicolumn{4}{|c|}{ Mortality \% in days } & $\begin{array}{c}\text { Total } \\
\text { mortali } \\
\text { ty \% }\end{array}$ & $\begin{array}{c}\text { Re- } \\
\text { isolat } \\
\text { ion }\end{array}$ \\
\hline 1. & A & 8 & $125 / \mathrm{ml}$ & 0 & 25 & 37.5 & 37.5 & 0 & 100 & + \\
\hline 2. & B & 8 & $8 \times 10^{8} / \mathrm{ml}$ & 0 & 25 & 0 & 12.5 & 37.5 & 75 & + \\
\hline 3. & C & 8 & $2 \times 10^{3} / \mathrm{ml}$ & 25 & 25 & 50 & 0 & 0 & 100 & + \\
\hline
\end{tabular}

*A-Aphanomyces laevis, B-Aspergillus niger, C-Saprolegnia parasitica 


\section{Indo Global Journal of Pharmaceutical Sciences, 2014; 4(2): 41-46}

A.niger:-The fish challenged with A.niger showed some change in swimming and on fourth day $25 \%$ mortality was observed. On sixth day dark patches on skin was observed on three fishes and on $8^{\text {th }}$ day $12.5 \%$ mortality was recorded and on $10^{\text {th }}$ day $37.5 \%$ mortality was observed with dark patches on skin and de scaling in few areas. Ulcers not developed and total mortality was $75 \%$. Re isolation in all the infectd fishes was positive. The work on the pathogenicity of isolated species of fungi on gold fish is very rare and not well documented, however the given species of fungi have been reported as pathogenic on many ornamental fish by (Chauhan and Qureshi,1994; Sosa et al.,2007;Hussian et al.,2013and Chauhan et al.,2014).present work is in agreement with the reports of above workers.

Histopathological changes:-Tissue infected with S.parasitica showed loss of epidermis and necrotized hypodermis. Muscle layer shows inflammation with necrotic tissue debris and formation of number of well developed layered granulomas surrounded by hyphae. Granulomas showed fribrillar structures due to hyphal infection. A.laevis injected tissue showed more or less similar symptoms as that with S.parasitica. Necrotised epidermis and hypodermis with granulomatous response of musculature. Histological studies of tissue injected with A.niger showed no granuloma formation in musculature, no hyphae was seen in deeper layers although epidermis was degenerated and edema was observed in underlying hypodermis and musculature.(Fig-712). These histopathological findings are supported by reports of (Miyazaki and Egusa,1972; Hatai,1980; Hatai et al.,1994and Hussian et al.,2013). Granulomatous response due to Aphanomyces infection was also reported by (Qureshi et al.,2001;Sosa et al., 2007and Chauhan and Qureshi,2012).Persent findings are in support of above reports. Histopathological studies of tissue infected with A.niger did not show any granuloma formation, however degenerated musculature was observed with necrotized hypodermis and epidermis.

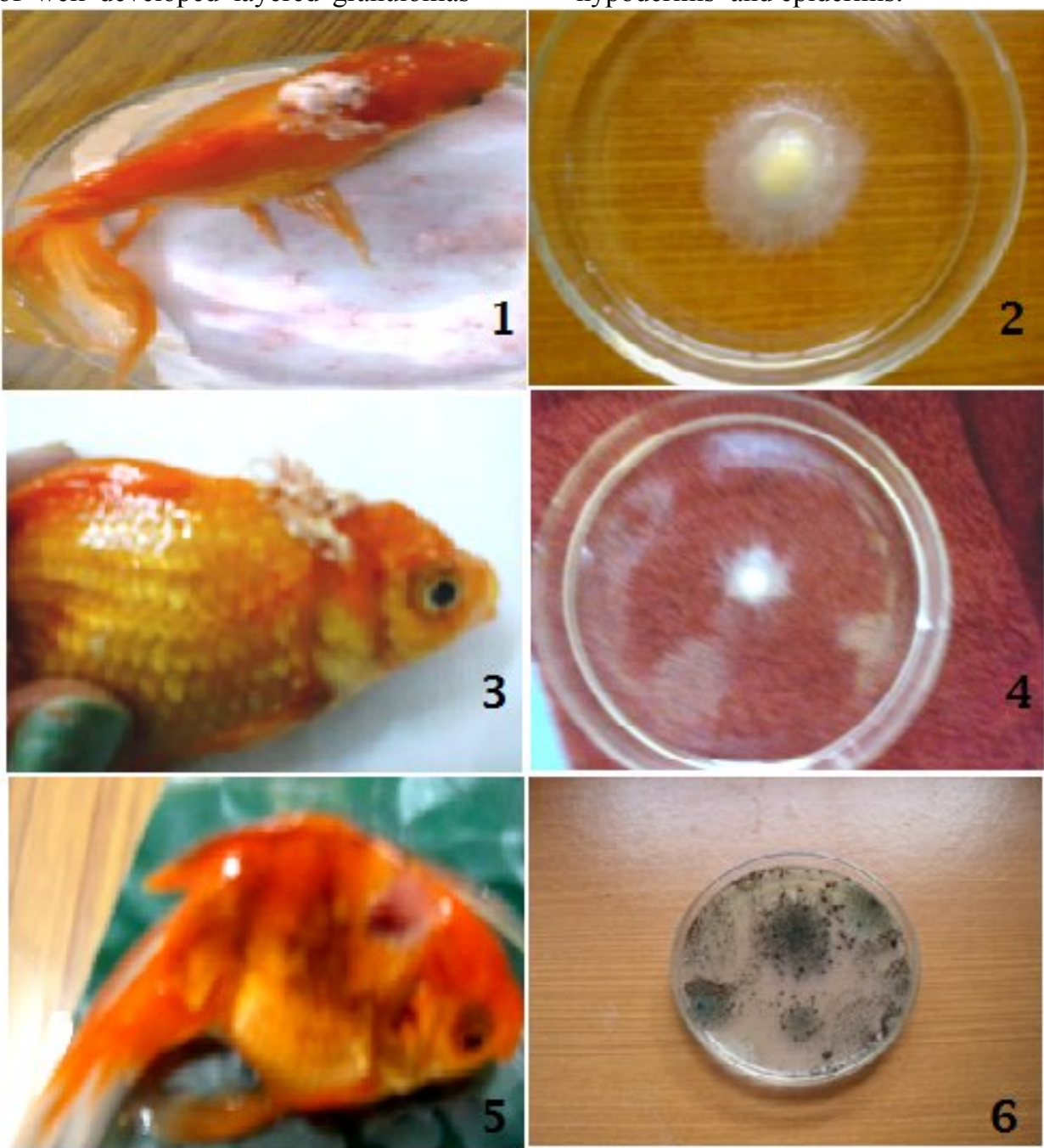

Fig- 1. Showing white fungoid patches of S.parasitica. Fig- 2. Wet colony of S.parasitica on Soya bean seed. Fig-3. Showing hyphal tufts of A.laevis on head region. Fig-4. Wet culture of A.laevis on Jowar seed.

Fig- 5. Showing black patches on skin due to A.niger infection. Fig-6. A.niger grown on Corn Meal Agar (CMA) 

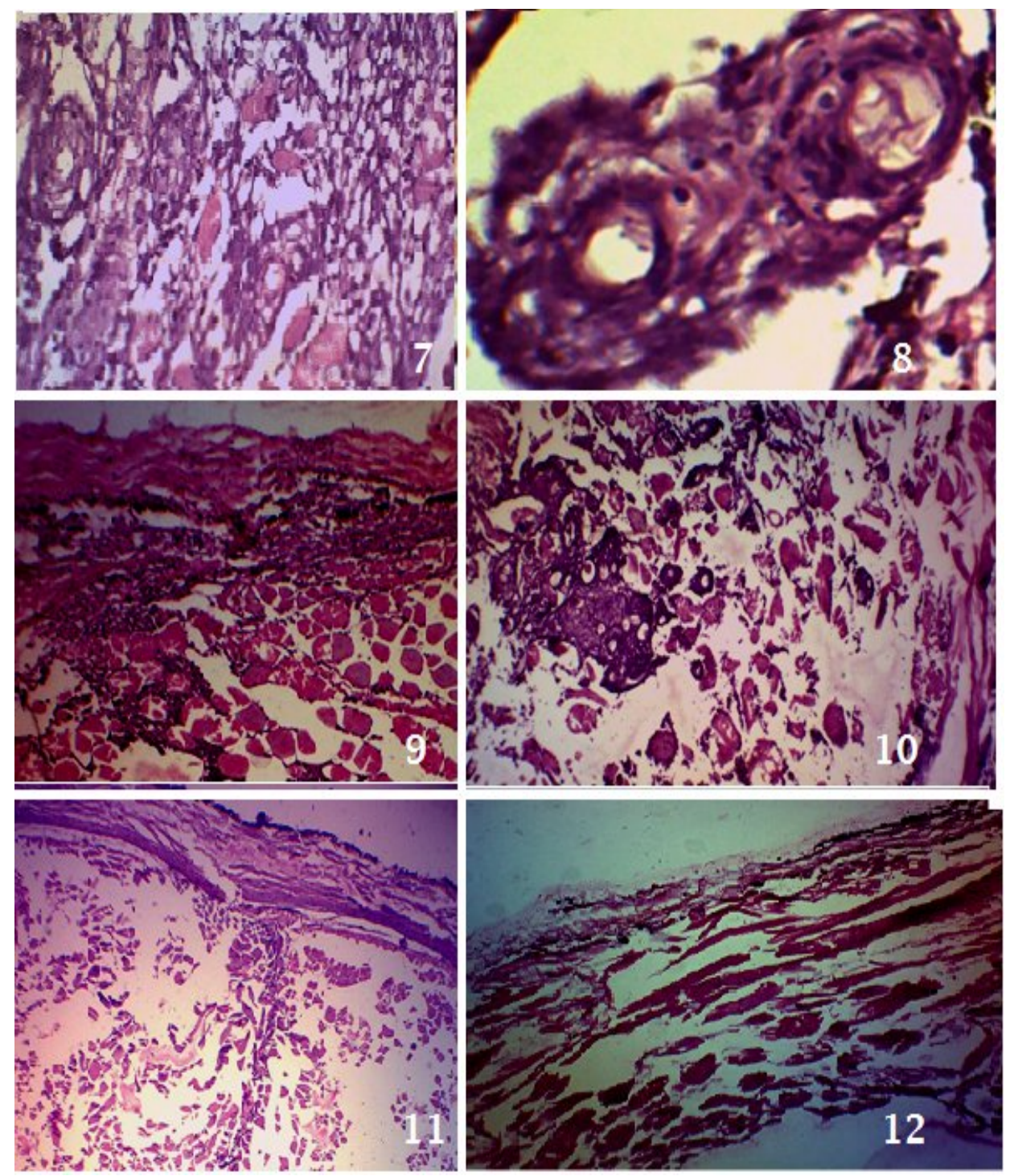

Fig-7 Showing many granulomas formed after penetration of hyphae of S.parasitica. Fig-8. Fibrillar granulomas in larger view surrounded by fungal hyphae. Fig-9.Showed lost epidermis, necrotized hypodermis in the tissue infected with A.laevis.

Fig-10.Degenerated muscle tissue with accumulated cells forming granulomas. Fig-11. Degenerated epidermis with necrotized hypodermis with the invasion of hyphae of A.niger. Fig-12.Necrotic changes in hypodermis and muscle fibers.

\section{CONCLUSON}

In the present study it was found that all the three species of isolated fungi were found to be pathogenic to gold fish and S.parasitica was most virulent.

\section{ACKNOWLEDGEMENT}

My sincere thanks to DST and my department. This work has been supported by Department of Science and Technology, New Delhi by providing funds and Head of the Department ,zoology and applied aquaculture, Barkatullah University, Bhopal for providing lab facilities for completion of this work.

\section{REFERENCES}

[1.] R.Chauhan. Study on certain fungal diseases in culturable and non- culturable species of fishes of Upper Lake , Bhopal. J. of Chemical , Biological and Physical Sciences.,2012 ,Vol.2, No.4, 1810-1815. 


\section{Indo Global Journal of Pharmaceutical Sciences, 2014; 4(2): 41-46}

[2.] R.Chauhan. Studies $\mathrm{n}$ conidial fungi isolated from some fresh water fishes. International journal of Advanced Life Sciences (IJALS).,2013, 6 (4) 2013,pp131-135.

[3.] R.Chauhan and M, Bankhede $M$. Studies on fungal population of Halali reservoir with respect to environmental conditions and its impact on fishes. International conference on waste wealth and health, 15-17 Feb , Bhopal.,2013 ,pp.128-133.

[4.] R.Chauhan , P. Kaur and S.Sharma . Pathogenicity of some species of Achyla and Saprolegnia on Indian major carps viz. Catla catla, Cirihinus mrigala and Labio rohita. JECET. September-November, 2012; Vol.1. No.3, 422428.

[5.] R. Chauhan, S.A,Lone and H. Beigh . Pathogenecity of three species of Aspergillus (A.fumigatus, A.niger \& A.sydowii) on some fresh water fishes. Science leaflets.,2014, vol.48.pp.65-72.

[6.]

R.Chauhan and T.A.Qureshi . Host range studies of Saprolegnia ferax and S.hypogyana on some freshwater fishes of Lower Lake of Bhopal. J. Inland Fish. Soc.,1994, 26 (2): 99-106.

[7.] R.Chauhan and T.A. Qureshi. Fungal infection of fishes. Published by Lap Lambert Academic Publishing, Germany.,2012. pp.1-174.

[8.] S.K.Das, M. Mumu ,A. Das A , I. Shakuntala , R.K, Das , S.V. Ngachan and S K Mjhi. Studies on the identification and control of a pathogen Saprolegnia infected Indian major carp fingerlings at mild altitude J. Envior.. Biol.,2012, 33, 545-549.

[9.] K. Hatai and S. Egusa. Studies on the pathogenic fungus of mycotic granulomatosis-I. Isolation and Network of Aquaculture Centres in Asia-Pacific,Bankok., 1977, 73 p.

[10.] K. Hatai. Studies on pathogenic agents of Saprolegniasis in fresh water fishes. Special ReNagasaki Pref. Inst. Fish.,1980, No. 8, 95 p.

[11.] K. Hatai and G. Hoshaiai . Mass mortality in cultured Coho salmon due to Saprolegnia parasitica coker.J. Wild 1. Dis., 1992,28(4):532-536.

[12.] K. Hatai ,K. Nakamura S.A. Rha ,K.Yuasa and S.Wada . Aphanomyces Infection in Dwarf Gourami (Colisa lalia) Division of Fish Diseases, Nippon Veterinary and Animal SciencUniversity,1-7-1 Kyonan-Cho, Musashino, 1984.Tokyo 180, Japan.

[13.] M.M.A.Hussian ,W.H. Hassan and M.A Mahmood .Pathogenicity of Achlya proliferoids and Saprolegnia diclina (Saprolegniaceae) associated with saprolegniasis outbreaks in cultured Nile Tilapia (Oreochromis niloticus). World J. of Fish and Marine Science.,2013, 5 (2);188-193.

[14.] Z.Iqbal ,U. Sheikh and R. Mughal . Fungal infections in some economically important freshwater fishes. Pak. Vet. J.,2012, 32(3) 422-426.

[15.] Z. Iqbal and R.Mumtaz. Some fungal pathogens of an ornamental fish, Black Moor (Carassius auratus L.) European Journal of Veterinary Medicine.,2013, 2 .No. 1, 1-10 ISSN 2051-297X.
[16.] R.D. Khulbe . Studies on aquatic fungi in relation to fish disease in Kumaun Himalaya. Plant and Nature.,1983, 1(1) 65-67.

[17.] R.D. Khulbe .Infection ability of water molds in some temperate fishes of Himalaya,India.Mykosen., 1989,(32);84-86.

[18.] R.D. Khulbe . A manual of aquatic fungi.Daya publishing house,Delhi.,2001,pp.1-254.

[19.] T.Myiazaki and S. Egusa . Studies on mycotic granulomatosis in fresh water fishes1. Mycotic granulomatosis in gold fish. Fish pathology.,1972, 7:15-25.

[20.] T.A.Qureshi , R.Chauhan and S.A.Mastan . Histopathology of mycoses in certain fishes of Bhopal. Indian J. Anim. Hlth.,2001, 40 (1): 93-96.

[21.] T.A.Qureshi, R.Chauhan and S.A .Mastan . Experimental infection of Saprolegnia spp. on different species of fish. J. Nat. Con., 2002, Vol. 14 (2): 385-388.

[22.] K.B.Raper and D.I.Fennell . The Genus Aspergillus.Williams and Wilkins, Baltimore., 1965.PP164.

[23.] M. Refai, M.M. Abdel , M.M.H. Afify ,H. Youssef and K.M. Marzou . Studies on aspergillomycosis in catfish (Clarias Lasera). Allgemeine Pathologic and pathologische Anatomic. Tagung der Deutachen Veterinar Medizinischen Gesellschaft. der Europeischen Gesellschaft fur Vet. Pathol.,1987, 1(i): 65-67.

[24.] M.K. Refai, A. Laila ,M.K. Mohamed and S.M.S. Shimaa . The assessment of Mycotic settlement of freshwater fishes in Egypt. J. Amer. Sci.,2010, 6(11), 595- 602.

[25.] A.Salem , M.Refai ,I.A. Eissa ,M. Mmarzouk ,M.R.Baki ,A. Mustafa and Mandmanal, Some studies on aspergillomycosis in Tilapianilotica. Zagazig Vet. J.,1989, 17(3) : 315-328.

[26.] S.C.Sati, G.S. Mer, R.D.Khulbe .Studies on parasitic water molds: some new host records of Saprolegnia parasitica Coker, Mykosen.,1982,25:638-640.

[27.] N. Shahbazain ,M. Ebrahimzadeh ,M. Soltani , S.R.Khosravi ,S. Mirzagai and I.Sharifpour . Fungal contamination in rainbow trout eggs in kermanshah province propagation with emphasis on Saprolegniaceae. Iran. J. Fish Sci.,2010. 9: 151-160

[28.] G.C.Shrivastava and R.C. Shrivastava . Ability of Saprolegniaceous fungi to parasitize Colisa fasciatusB1. Geobios.,1977a, 4:31-32.

[29.] R.C.Shrivastava .Fungi parasitizing the eggs of certain fresh water fishes, mycopathologia., 1979b ,68(3):167-169

[30.] A.K.Shristava .Record of Aspergillus terreus (Thorn.) Fungi as fish pathogen.Indian J of fish .,1996,43, 2,203204 pp.

[31.] R.C.Srivastava. Fish Mycopathology. Today and tomorrow's Printers and Publishers New Dehli,,2009, pp: 103.

[32.] M.M.R.Siddique , M.A Bashar M.A, Hussain and A.S.M. Kibria. Fungal Disease of FreshwaterFishes in Natore District of Bangladesh. J. Bangla. Agri. Uni.,2009, 7(1), 157-162 . 
Indo Global Journal of Pharmaceutical Sciences, 2014; 4(2): 41-46

[33.] E.J.Sosa , J.H. Landsberg , Y. Kiryu , C.M. Stephenson,T.T. Cody, A.K.Duckmen and H.Wolfe . Pathogenicity studies wiyh the fungi Aphanomyces invadans, Achlya bisexualis and Phialemonium

dimorphosporum: Induction of skin ulcers in striped mullet.Journal of aquatic animal health., 2007,19:41-48.

[34.] W.N.Tiffney. The host range of Saprolegnia parasitica.Mycologia., 1939,31;310-321.

[35.] L.G,Willoughby . Fungi and Fish Diseases.Pisces Press, Stirling, UK.1994 p. 57.

Indo Global Journal of Pharmaceutical Sciences( ISSN 22491023 ; CODEN- IGJPAI; NLM ID: 101610675) indexed and abstracted in EMBASE(Elsevier), SCIRUS(Elsevier),CABI, CAB Abstracts, Chemical Abstract Services(CAS), American Chemical Society(ACS), Index Copernicus, EBSCO, DOAJ, Google Scholar and many more. For further details, visit 